\title{
Temporal and spatial distribution of the meiobenthic community in Daya Bay, South China Sea
}

L. Tang ${ }^{1,2}$, H. X. Li ${ }^{1}$, and Y. Yan ${ }^{1}$

${ }^{1}$ CAS Key Laboratory of Marine Bio-resources Sustainable Utilization, Guangzhou 510301, China

${ }^{2}$ Graduate University of Chinese Academy of Sciences, Beijing 10039, China

Received: 12 March 2012 - Accepted: 11 April 2012 - Published: 24 April 2012

Correspondence to: Y. Yan (yany@scsio.ac.cn)

Published by Copernicus Publications on behalf of the European Geosciences Union.
Temporal and spatial distribution of the meiobenthic community

T. Ling et al.

\section{Title Page}

\section{Full Screen / Esc}

Printer-friendly Version

Interactive Discussion 


\section{Abstract}

Spatial and temporal biodiversity patterns of the meiobenthos were studied for the first time in Daya Bay, which is a tropical semi-enclosed basin located in the South China Sea. The abundance, biomass, and composition of the meiobenthos and the

basic environmental factors in the bay were investigated. The following 19 taxonomic groups were represented in the meiofauna: Nematoda, Copepoda, Polychaeta, Oligochaeta, Kinorhyncha, Gastrotricha, Ostracoda, Bivalvia, Turbellaria, Nemertinea, Sipuncula, Hydroida, Amphipoda, Cumacea, Halacaroidea, Priapulida, Echinodermata, Tanaidacea, and Rotifera. Total abundance and biomass of the meiobenthos showed great spatial and temporal variation, with mean values of $993.57 \pm$ $455.36 \mathrm{ind} \mathrm{cm}^{-2}$ and $690.51 \pm 210.64 \mu \mathrm{g} 10 \mathrm{~cm}^{-2}$, respectively. Nematodes constituted $95.60 \%$ of the total abundance and thus had the greatest effect on meiofauna quantity and distribution, followed by copepods $(1.55 \%)$ and polychaetes (1.39\%). Meiobenthos abundance was significantly negatively correlated with water depth at stations $15(r=-0.747, P<0.05)$ and significantly negatively correlated with silt-clay content $(r=-0.516, P<0.01)$ and medium diameter $(r=-0.499, P<0.01)$ of the sediment. Similar results were found for correlations of biomass and abundance of nematodes with environmental parameters. Polychaete abundance was positively correlated with the bottom water temperature $(r=0.456, P<0.01)$. Meiobenthos abundance differed significantly among seasons $(P<0.05)$, although no significant difference among stations and the interaction of station $\times$ season was detected by two-way ANOVA. In terms of vertical distribution, most of the meiobenthos was found in the surface layer of sediment. This pattern was apparent for nematodes and copepods, but a vertical distribution pattern for polychaetes was not as obvious. Based on the biotic indices and be influenced by environmental variations.

OSD

$9,1853-1885,2012$

\section{Temporal and spatial distribution of the meiobenthic community}

T. Ling et al.

\section{Title Page}




\section{Introduction}

Meiofauna are defined as metazoan invertebrates that are smaller than $500 \mu \mathrm{m}$ in size and are retained on sieve meshes of 31-64 $\mu \mathrm{m}$ (Coull and Chandler, 2001). Meiofauna are effective decomposers of organic material (Giere, 1993) and active consumers of 5 benthic bacteria and microalgae, thus they are intimately associated with the benthic marine environment (Heip et al., 1985). Meiofauna exhibit high abundance, diversity, and productivity in most sedimentary habitats, and they play an important role in marine benthic food chains due to their small size, high abundance, fast turnover rates, and rapid generation times (Heip et al., 1985; Gee, 1989; Coull, 1999). Because of their biological characteristics, meiofaunal communities can be used to monitor marine environments, evaluate the effects of human activity on marine environments, and verify hypotheses about different ecosystems (Schratzberger et al., 2004; Veit-Kahler et al., 2008).

Daya Bay is a semi-enclosed bay located in the Northern South China Sea (from $15113^{\circ} 29^{\prime} 42^{\prime \prime}$ to $114^{\circ} 49^{\prime} 42^{\prime \prime} \mathrm{E}, 23^{\circ} 31^{\prime} 12^{\prime \prime}$ to $24^{\circ} 50^{\prime} 00^{\prime \prime} \mathrm{N}$ ). Its coastal line is $92 \mathrm{~km}$, and it has an area of $600 \mathrm{~km}^{2}$ (Wang et al., 2006, 2008). The water depth ranges from 6 to $16 \mathrm{~m}$, with an average of $10 \mathrm{~m}$ (Xu, 1989; Wang et al., 2006, 2008; Wu and Wang, 2007). It is a typical subtropical bay in the South China Sea, and it is important because of its natural resources and habitat diversity (e.g., mangroves and coral communities). Daya Bay and its adjacent areas have become an important economic development district, in which molluscs and fish are being cultivated (Wang et al., 2008). Wang et al. (2008) reported that the ecological environment of Daya Bay changed substantially between 1982 and 2004, with an increased average N/P ratio (from 1.377 to 49.09), decreased numbers of phytoplankton species (from 159 species, 46 genera to 126 25 species, 44 genera) and zooplankton species (from 46 species to 36 species), and reduced megabenthos biomass. However, meiofauna were not included in that investigation, and the biomass and distribution of meiobenthic organisms in Daya Bay were unknown.
OSD

$9,1853-1885,2012$

\section{Temporal and spatial distribution of the meiobenthic community}

T. Ling et al.

Title Page

\section{4}

Back

Close

\section{Full Screen / Esc}

Printer-friendly Version

Interactive Discussion 
In this study, the composition, abundance, biomass, diversity, and distribution of the meiofauna were investigated in Daya Bay from October 2009 to August 2010. The relationships among these parameters and basic environmental factors were analyzed to assess the biodiversity patterns of the meiobenthos in this ecosystem and to evaluate 5 the potential response of the meiofauna to changes in the ecological environment of Daya Bay.

\section{Materials and methods}

\subsection{Field studies}

Field sampling of sediment was conducted at quarterly intervals (October 2009 (au10 tumn), January 2010 (winter), April 2010 (spring), and August 2010 (summer) at nine stations in Daya Bay (S4, S6, S7, S8, S10, S11, S12, S14, and S15), which were located using a global positioning system (Fig. 1). At each station, three replicate sediment samples were collected using a $0.1 \mathrm{~m}^{2}$ Gray-Ohara box grab. When the box grab was onboard the ship, one subsample from each grab was collected for the meio15 fauna analysis using a cut-off syringe $\left(2.9 \mathrm{~cm}\right.$ diameter, $6.6 \mathrm{~cm}^{2}$ surface area) pushed to $10 \mathrm{~cm}$ depth in the sediment. The sample was divided into three vertical layers $(0-2$, $2-5$, and $5-10 \mathrm{~cm}$ ) and then was fixed with $4 \%$ formalin separately. A core was taken from each of the three box grabs at a given site at each time point to promote randomness in the sampling process except in January 2010. Another subsample of the surface sediment from each box grab was taken for analysis of water content and particle size, and three subsamples were taken for analysis of water content, chlorophyll-a (Chl-a), total organic carbon and granularity of sediment. Sediment samples for environmental analysis were sorted into PVC valve bags, placed in an ice box on board, and later transferred to the laboratory for storage at $-20^{\circ} \mathrm{C}$ until analysis. Temperature, salinity of bottom water, and the depth of each station were measured at three regions within each station at each sampling time point using a CTD.
OSD

$9,1853-1885,2012$

\section{Temporal and spatial distribution of the meiobenthic community}

T. Ling et al.

Title Page 


\subsection{Laboratory procedures}

Meiofauna were extracted from the sediment using the Ludox ${ }^{\mathrm{TM}}$ centrifugation technique (Heip et al., 1985). All biological core samples were stained with Rose Bengal for at least $24 \mathrm{~h}$ and then washed with tap water under a set of sieves with mesh sizes of

$538 \mu \mathrm{m}$ to $500 \mu \mathrm{m}$. Meiofauna were extracted from the remaining sand particles retained on the smallest mesh size by centrifugation with colloidal silica polymer (Ludox ${ }^{\mathrm{TM}}-50$, $1.15 \mathrm{~g} \mathrm{~cm}^{-3}$, Sigma-Aldrich, St. Louis, Mo, USA). Centrifugation was repeated three times at $1800 \mathrm{r}$ for $10 \mathrm{~min}$ each time. After each centrifugation, the floating matter was washed and decanted into a lined Petri dish, and the meiofauna were sorted, identi10 fied, and counted under a stereoscopic microscope (Widbom, 1984; Higgins and Thiel, 1988; Giere, 1993).

The sediment samples, except those for water content and particle size analysis, were frozen at $-20^{\circ} \mathrm{C}$ for $24 \mathrm{~h}$, followed by freeze-drying. The freeze-dried sediment was homogenized manually and stored in desiccators for further analyses. The sam15 ples for Chl-a was placed in a $50 \mathrm{ml}$ polyethylene bottle with $30 \mathrm{ml}$ of $90 \%$ acetone for the extraction of pigments. Chl-a concentrations were measured using a 10- AU Turner Designs fluorometer (Turner Designs, Sunnyvale CA, USA) fitted with the narrow-band, non acidification system of Welschmeyer (1994) (Nozais et al., 2001). The total organic carbon (TOC) in these samples was estimated using the wet oxidation method (El-Wakeel and Riley, 1957), and then TOC content was then converted to organic matter (OM) content (Wiseman and Bennette, 1960). Fresh wet sediment samples with a known weight were dried at $105^{\circ} \mathrm{C}$ for $24 \mathrm{~h}$ and the final dry weight was measured. The water content was calculated as the sediment weight loss before and after drying. The particle size of sediments was determined in the Granularity Laboratory of Masterizer2000 (Malvern, Worcestershire, UK, 0.02-2000 $\mu \mathrm{m}$ ).

OSD

9, 1853-1885, 2012

\section{Temporal and spatial distribution of the meiobenthic community}

T. Ling et al.

\section{Title Page}

\section{Full Screen / Esc}

Printer-friendly Version

Interactive Discussion 


\subsection{Statistics}

All meiofaunal abundance data were expressed as individuals per $10 \mathrm{~cm}^{2}$ for each sample, and the biomass values of different taxonomic groups were calculated based on their dry weight following Gerlach (1971) and Widbom (1984).

5 The Shannon-Wiener diversity index $\left(H^{\prime}\right)$, the Margalef's index $(D)$ and the Pielou's evenness $\left(J^{\prime}\right)$ were used in characterization of meiofaunal community structure:

$H^{\prime}=-\sum n_{i} / N \log n_{i} / N$

$D=(S-I) / \ln R N$

${ }_{10} J^{\prime}=H^{\prime} / H_{\max }^{\prime}$

Where $n_{i}$ - is community density of each taxonomic groups, $N$ - total density of communities, $S$ - the number of taxonomic group.

Biological data were analyzed using univariate and multivariate methods. Pearson's correlation analysis was performed to examine the relationship among environmental factors and the relationship between meiofauna and environmental variables. Statistical differences among stations and seasons were tested by two-way analysis of variance (ANOVA) using the quantitative information about the meiofaunal assemblages (i.e., number of taxonomic groups, abundance, biomass, and biotic indices). These analyses were performed using the SPSS 17.0 statistical software package. The multivariate analysis followed the standard methods described in Clarke (1993) and used the PRIMER software 5.0 statistical package (Plymouth Routines in Multivariate Ecological Research). Environmental variables were first subjected to principal components analysis (PCA), to allow the identification of those most responsible for temporal and spatial variations. The Bray-Curtis similarity measure was used, after square root transformation of the data (Clarke and Gorley, 2006), for CLUSTER analysis and two-dimensional multidimensional scaling (MDS) ordination of environmental and meiofaunal parameters at the nine stations at four different time points (seasons). The map of the stations,
OSD

9, 1853-1885, 2012

\section{Temporal and spatial distribution of the meiobenthic community}

T. Ling et al.

Title Page

\section{4}

Back

Close

\section{Full Screen / Esc}

Printer-friendly Version

Interactive Discussion 
the horizontal and vertical distribution of meiofauna, the isolines was generated by using Surfer 8.0. And other calculation and tables were completed by using Microsoft Office Excel 2003.

\section{Results}

\section{$5 \quad 3.1$ Environmental parameters}

The water depth decreased from the outer stations to the inner stations of Daya Bay. The lowest mean water depth was $5.50 \pm 0.21 \mathrm{~m}$ at S8 and the deepest was $15.70 \pm 1.24 \mathrm{~m}$ at $\mathrm{S} 14$ (Fig. 2a). The average water temperature was $21.23 \pm 0.40^{\circ} \mathrm{C}$ in spring, $29.65 \pm 1.39^{\circ} \mathrm{C}$ in summer, $22.06 \pm 0.60^{\circ} \mathrm{C}$ in autumn, and $16.67 \pm 0.44^{\circ} \mathrm{C}$ in 10 winter (Fig. 2b), and mean annual temperature was $22.40 \pm 0.51^{\circ} \mathrm{C}$. Results of two-way ANOVA showed that there were significant differences in water temperature among seasons $(P<0.001)$, but there were no significant differences among stations. The salinity ranged between $28.54 \%$ and $33.66 \%$, with no significant spatial and temporal differences (Fig. 2c).

15 Five main categories of grain size were found in the sediments collected in the four seasons. Most samples were characterized as clay-silt, with $20.10-40.16 \%$ clay, 54.05-70.56\% silt, and 6.09-7.65 $\mathrm{gg}$ medium diameter (Md). Silt-sand was the second most common type of sediment sample, with $6.08-19.75 \%$ clay, $22.70-39.81 \%$ silt, and 2.93-5.35 $\mathrm{\mu g} \mathrm{Md}$. Other types of sediment found were clay-sandy silt, sandy silt, and mid-silt. There was no significant difference in granularity among stations or seasons.

Water content was stable across seasons but showed a clear difference among stations (range, $45.32 \%$ to $65.85 \%$ ) (Fig. 3a). The TOC levels in sediments varied between $0.66 \%$ and $2.99 \%$, with no significant spatial and temporal differences (Fig. 3b).

Chl-a content in sediments collected in Daya Bay showed clear seasonal changes, with content in autumn $>$ summer $>$ winter $>$ spring. In autumn, the mean Chl-a content

\section{OSD}

9, 1853-1885, 2012

\section{Temporal and spatial distribution of the meiobenthic community}

T. Ling et al.

\section{Title Page}

\section{Full Screen / Esc}

Printer-friendly Version

Interactive Discussion 
in sediment was $2.32 \pm 0.98 \mu \mathrm{g} \mathrm{g}^{-1}$, the lowest value was $1.33 \mu \mathrm{gg}^{-1}$ at $\mathrm{S} 10$, and the highest value was $4.13 \mathrm{\mu g} \mathrm{g}^{-1}$ at $\mathrm{S} 15$ (Fig. 4a). In winter, the mean Chl-a content was

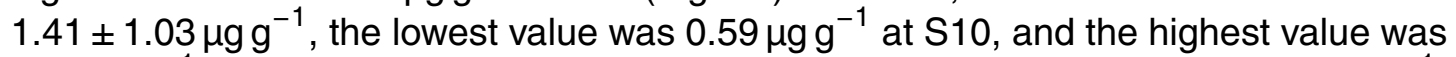
$3.99 \mu^{-1}$ at $\mathrm{S} 11$ (Fig. 4b). In spring, the mean Chl-a content was $1.02 \pm 0.59 \mu^{-1} g^{-1}$, 5 the lowest value was $0.67 \mu_{g_{g}}^{-1}$ at $\mathrm{S} 7$, and the highest value was $2.54 \mu_{\mathrm{g} \mathrm{g}}{ }^{-1}$ at $\mathrm{S} 12$ (Fig. 4c). In summer, the mean Chl-a content was $2.21 \pm 0.55 \mathrm{\mu g} \mathrm{g}^{-1}$, the lowest value was $1.55{\mu g^{-1}}^{-1} \mathrm{~S} 7$, and the highest value was $2.68 \mu \mathrm{g} \mathrm{g}^{-1}$ at $\mathrm{S} 11$ (Fig. $4 \mathrm{~d}$ ). Results of two-way ANOVA showed that there were significant differences in Chl-a content of the sediment among seasons $(P=0.02)$, but no differences among stations were 0 detected.

The vertical distribution of Chl-a in sediment samples collected in autumn was as follows: $0.59-2.14{\mu g ~ g^{-1}}$ in the $0-2 \mathrm{~cm}$ layer, $0.30-1.69{\mu g ~ g^{-1}}$ in the $2-5 \mathrm{~cm}$ layer, and $0.27-1.0 \mu^{-1}$ in the $5-10 \mathrm{~cm}$ layer. In summer, the values were $0.61-0.97{\mu g^{-1}}^{-1}$, $0.45-1.57 \mu^{-1} g^{-1}$, and $0.40-1.08{\mu g^{-1}}$, respectively. ANOVA results showed no sig15 nificant differences in the layered distribution of Chl-a. Vertical distribution differed significantly among stations, but no significant differences among seasons or for the interaction of station and season were detected.

Pearson correlation analysis revealed a significant positive correlation between salinity and water and the Md and clay-silt content of the sediment. Water content of the 20 sediment was negatively correlated with water depth and positively correlated with granularity of the sediment. Chl-a content of the sediment was negatively correlated with temperature of the bottom water (Table 1).

Figure 5 shows the matrix of contributions of environmental variables on principal component axes 1 and 2. Principal components analysis (PCA) revealed that $60.9 \%$ 25 of the total variation was encompassed by axes 1 and 2 . The results showed that the sand content of sediment decreased from left to right; the clay-silt content and Md of the sediment increased on axis 1; and depth, salinity, and TOC increased on axis 2.

CLUSTER analysis revealed that the environmental parameters of the same station could be clustered together in different seasons, exhibiting a high similarity. The

OSD

9, 1853-1885, 2012

\section{Temporal and spatial distribution of the meiobenthic community}

T. Ling et al.

Title Page

\section{4}


following five groups showed a similarity level of 95\%: (1) S6 for all four seasons, S10 in autumn, spring, and summer, and S11 and S8 in autumn, winter, and summer constituted group 1; (2) S12 for all four seasons, S14 in autumn, winter, and spring, and S4, S7, and S10 in winter made up group 2; (3) S15 for all four seasons and S14 in 5 summer represented group 3; (4) S4, S8, and S11 in spring made up group 4; and (5) S7 in autumn, spring, and summer and S4 in autumn and summer composed group 5 (Fig. 6).

\subsection{Taxonomic composition, abundance, and biomass of meiofauna}

The following 19 taxonomic groups were represented in the meiofauna collected at the nine stations during the four seasonal sampling events: Nematoda, Copepoda, Polychaeta, Oligochaeta, Kinorhyncha, Gastrotricha, Ostracoda, Bivalvia, Turbellaria, Nemertinea, Sipuncula, Hydroida, Amphipoda, Cumacea, Halacaroidea, Priapulida, Echinodermata, Tanaidacea, and Rotifera (Appendice). The average abundance and biomass of meiofauna collected from the nine stations during the four seasons were

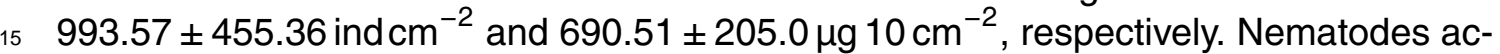
counted for $95.60 \%$ of the abundance of meiofauna. Copepods and polychaetes ranked second in abundance ( $1.55 \%$ and $1.39 \%$, respectively). Nematodes constituted $55.02 \%$ of biomass, followed by polychaetes at $28.01 \%$. The number of taxonomic group, abundance, and biomass of the meiobenthos from Daya Bay all differed significantly among stations and seasons (two-way ANOVA, $P<0.001$ ).

\subsection{Temporal distribution of meiofauna}

In autumn, the highest and lowest abundance of meiobenthos occurred at S4 and S8, with 939.7 ind $10 \mathrm{~cm}^{-2}$ and 233.2 ind $10 \mathrm{~cm}^{-2}$, respectively. Nematodes were dominant at $92.28 \%$ (range, $224.7-821.5 \mathrm{ind} 10 \mathrm{~cm}^{-2}$ ), followed by polychaetes at $2.05 \%$ (range, $2.5-39.4$ ind $10 \mathrm{~cm}^{-2}$ ). In winter, the highest and lowest abundance of meiobenthos was found at $\mathrm{S} 15$ and $\mathrm{S} 10$, with 1088.08 ind $10 \mathrm{~cm}^{-2}$ and 424.63 ind $10 \mathrm{~cm}^{-2}$, respectively.
OSD

$9,1853-1885,2012$

\section{Temporal and spatial distribution of the meiobenthic community}

T. Ling et al.

\section{Title Page}


Nematodes were dominant at $94.98 \%$ (range, $393.66-1021.60 \mathrm{ind} 10 \mathrm{~cm}^{-2}$ ), followed by copepods at $2.26 \%$ (range, $0.67-39.21$ ind $10 \mathrm{~cm}^{-2}$ ). In spring, the highest and lowest abundance of meiobenthos occurred at S4 and S7, with $2301.88 \mathrm{ind} 10 \mathrm{~cm}^{-2}$ and 650.83 ind $10 \mathrm{~cm}^{-2}$, respectively. Nematodes were dom-

5 inant at $97.63 \%$ (range, 623.06-2240.79 ind $10 \mathrm{~cm}^{-2}$ ), followed by copepods at $0.91 \%$ (range, $3.03-26.26$ ind $10 \mathrm{~cm}^{-2}$ ). In summer, the highest and lowest abundance of meiobenthos was found at $\mathrm{S} 11$ and $\mathrm{S} 15$, with $1895.43 \mathrm{ind} 10 \mathrm{~cm}^{-2}$ and 313.80 ind $10 \mathrm{~cm}^{-2}$, respectively. Nematodes were dominant at $94.87 \%$ (range, 294.11-1844.94 ind $10 \mathrm{~cm}^{-2}$ ), followed by polychaetes at $2.47 \%$ (range, 4.5410111.08 ind $10 \mathrm{~cm}^{-2}$ ). The abundance of total meiobenthos, nematodes, and polychaetes differed significantly among stations and months; however, this was not true for copepod abundance. The interaction of station $\times$ season was significant difference for polychaete abundance from ANOVA results; however for abundance of total meiobenthos, nematodes, and copepod showed different trends.

\subsection{Spatial distribution of meiofauna}

\subsubsection{Horizontal distribution}

The highest mean abundance of meiobenthos of the four seasons occurred at S4 $\left(1397.81 \pm 725.76\right.$ ind $\left.10 \mathrm{~cm}^{-2}\right)$, followed by $S 11\left(1294.12 \pm 850.32\right.$ ind $\left.10 \mathrm{~cm}^{-2}\right)$. The lowest mean abundance was found at $S 7\left(623.09 \pm 135.04\right.$ ind $\left.10 \mathrm{~cm}^{-2}\right)$ (Fig. 7a). The mean abundance of meiofauna of seasons differed significantly among stations. The horizontal distribution of nematodes showed the same trend as that of the total meiofauna, with the highest abundance at S4 $\left(1325.73 \pm 738.76\right.$ ind $\left.10 \mathrm{~cm}^{-2}\right)$ and the lowest at $\mathrm{S} 7\left(577.86 \pm 146.07 \mathrm{ind} 10 \mathrm{~cm}^{-2}\right)(\mathrm{Fig} .7 \mathrm{~b})$. The highest abundance of copepods occurred at $S 4\left(20.38\right.$ ind $\left.10 \mathrm{~cm}^{-2}\right)$, followed by value for $S 15$, and the lowest abundance $\left(29.49\right.$ ind $\left.10 \mathrm{~cm}^{-2}\right)$ and the lowest was value at S6 (Fig. 7d).

OSD

9, 1853-1885, 2012

\section{Temporal and spatial distribution of the meiobenthic community}

T. Ling et al.

Title Page

4 


\subsubsection{Vertical distribution}

The vertical distribution of meiobenthos at the nine stations was studied in all seasons except winter (Fig. 8). The greatest abundance of meiobenthos (50.77\%) occurred in the upper layer $(0-2 \mathrm{~cm})$, and the number of organisms gradually declined 5 with depth $(31.63 \%$ in the $2-5 \mathrm{~cm}$ layer and $17.60 \%$ in the $5-10 \mathrm{~cm}$ layer). As the dominant group, the distribution of nematodes was highly similar to that of the total meiobenthos: $50.77 \%, 30.55 \%$, and $18.68 \%$ were found in the $0-2 \mathrm{~cm}, 2-5 \mathrm{~cm}$, and 5-10 cm layers, respectively. A large proportion of the copepods occurred in the upper layer $(74.27 \%)$, and the percentages in the deeper two layers were similar $(12.56 \%$ 10 and $13.16 \%$, respectively). Almost half of the polychaetes $(50.89 \%)$ were found in the upper layer, with $22.17 \%$ in the $2-5 \mathrm{~cm}$ layer and $26.94 \%$ in the $5-10 \mathrm{~cm}$ layer. The taxonomic composition and abundance of the meiobenthos and the abundance of nematodes and copepods were significantly different among the vertical layers $(P<0.001)$. Moreover, the vertical distribution of the taxa, the abundance of meiobenthos, and the

\subsection{Distribution of meiobenthos biomass}

The temporal and spatial distribution of biomass was similar to that of abundance. The

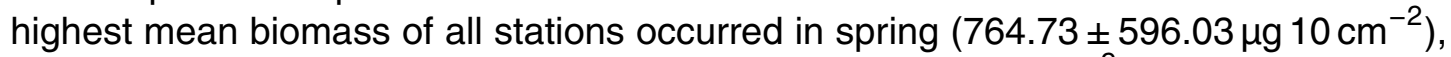

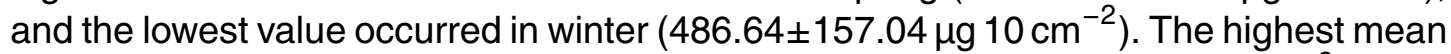
20 biomass of the meiobenthos of four seasons was $1121.22 \pm 358.64 \mu \mathrm{g}^{-2} \mathrm{~cm}^{-2}$ at S4, and the lowest value was $395.10 \pm 102.44 \mu \mathrm{g} 10 \mathrm{~cm}^{-2}$ at $\mathrm{S} 6$. The biomass of meiobenthos differed significantly among stations, seasons, and interaction of station $\times$ season. In terms of vertical distribution, more than half $(51.95 \%)$ of the biomass was found in the $0-2 \mathrm{~cm}$ layer, with $26.99 \%$ and $21.64 \%$ in the $2-5 \mathrm{~cm}$ and $5-10 \mathrm{~cm}$ layers, respectively. Thus, the biomass differed significantly among layers. Pearson correlation analysis showed that the biomass in the $0-2 \mathrm{~cm}$ layer was significantly positively correlated with the abundance of nematodes, copepods, polychaetes, and total meiobenthos in

\section{OSD}

$9,1853-1885,2012$

\section{Temporal and spatial distribution of the meiobenthic community}

T. Ling et al.

\section{Title Page}

\section{4}

Back

Close

\section{Full Screen / Esc}

Printer-friendly Version

Interactive Discussion 
the $0-2 \mathrm{~cm}$ layer. The biomass in the $2-5 \mathrm{~cm}$ layer also was significantly positively correlated with the abundance of nematodes, copepods, polychaetes, and total meiobenthos in the $2-5 \mathrm{~cm}$ layer. The biomass in the $5-10 \mathrm{~cm}$ layer was significantly positively correlated with the abundance of nematodes, copepods, and total meiobenthos in the 5 5-10 cm layer, but not with polychaete abundance.

\subsection{Correlations between the meiobenthos and environmental parameters}

The number of taxonomic group was significantly negatively correlated with the bottom water temperature. Meiobenthos abundance was significantly negatively correlated with water depth at stations and significantly negatively correlated with silt-clay content and Md of the sediment. Similar results were found for correlations of biomass and abundance of nematodes with environmental parameters. Polychaete abundance was positively correlated with the bottom water temperature. There were no significant correlations between the other biotic variables and environmental parameters. Pearson correlation analyses of diversity indices and environmental parameters indicated content of the sediment, and $\mathrm{J}^{\prime}$ was significantly negatively correlated bottom water temperature (Table 2).

Ordination of the samples using the MDS technique showed meiobenthos assemblages was similar by season than by station (Fig. 9). Some samples belonging to the same season were clustered together (e.g., April), but samples from different stations were characterized by higher variability. Because nematodes constituted the largest proportion of the total meiobenthos abundance, two-way ANOVA showed the same results that biotic variations include the taxonomical groups, abundance and biomass among seasons were significant difference, but not different on stations and interaction
OSD

$9,1853-1885,2012$

\section{Temporal and spatial distribution of the meiobenthic community}

T. Ling et al.

\section{Title Page}

\section{4}




\section{Discussion}

This study was the first to explore statistically the ways in which community composition, abundance, biomass, and distribution of the meiobenthos differ throughout Daya Bay over the course of a year. This approach enabled exploration of which environmen5 tal variables were mainly responsible for influencing the spatial and temporal distributions of the meiobenthos. Integration of the results provided a quantitative description of the biodiversity patterns of the meiobenthos on temporal and spatial (horizontal and vertical) scales as well as a relatively good characterization of the environment.

Nineteen taxonomic groups of meiofauna were found in Daya Bay, which was higher 10 than in Ha Long Bay, South China Sea (11 groups) (Olga et al., 2008) and lower than in Nha Trang Bay, South China Sea (26 groups) (Olga et al., 2006). Free-living marine nematodes constituted as much as $95.60 \%$ of the total individuals for the four seasons studied herein, followed by copepods (1.55\%). This finding is in agreement with results of previous studies conducted in the South China Sea (Olga et al., 2006, 15 2008; Liu, 2009) and other areas (Olafsson, 1997; Armenteros et al., 2009). The mean abundance of meiofauna $\left(993.57 \pm 455.36 \mathrm{ind} \mathrm{cm}^{-2}\right)$ in Daya Bay was similar to that at Cienfuegos in the Caribbean $\left(780.02 \pm 772\right.$ ind $10 \mathrm{~cm}^{-2}$ ) (Armenteros et al., 2009) and in Nha Trang Bay, South China Sea $\left(944.3 \pm 303.7-1034.6 \pm 435.8\right.$ ind $\left.10 \mathrm{~cm}^{-2}\right)$ (Olga et al., 2006) and higher than that reported for Victoria Bay in Hong Kong 20 (182.7-290.2 ind $10 \mathrm{~cm}^{-2}$ ) (Liu, 2010) and for Ha Long Bay, South China Sea (180.8 \pm $13.1 \mathrm{ind} 10 \mathrm{~cm}^{-2}$ ) (Olga et al., 2008). The abundance of meiobenthos found in the present study was lower than the $3275 \pm 701$ ind $10 \mathrm{~cm}^{-2}$ reported for the southwest lagoon of New Caledonia (Boucher, 1997), the 1524-6094 ind $10 \mathrm{~cm}^{-2}$ found in the Yellow Sea (Kim et al., 2000), and the $810 \pm 410$ ind $10 \mathrm{~cm}^{-2}$ collected from the East 25 China Sea (Zhang et al., 2001, 2002), but there were no distinct differences among the taxonomic groups identified.

Our results demonstrated that the community composition and abundance of the meiofauna in Daya Bay are influenced markedly by both station and season. In terms of
OSD

$9,1853-1885,2012$

\section{Temporal and spatial distribution of the meiobenthic community}

T. Ling et al.

\section{Title Page}


spatial variation, granulometric composition of the sediments was a key factor that determined the distribution and taxonomic composition of the meiobenthos. Nematodes, which represented the dominant taxonomic group, were significantly negatively correlated with the silt-clay content and Md of the sediment. This determined the abundance 5 of the meiobenthos at the different stations. Another key factor affecting the meiofaunal community structure was water depth: It was negatively correlated with the densities of nematodes and copepods, which were the most two important meiobenthic taxonomic groups in Daya Bay. The Chl-a and OM contents of the sediment, which were reported to influence community structure in previous studies (Gritta et al., 2008), were not cor10 related with abundance of the meiobenthos in this study. Because the area of Daya Bay is so small, it is likely that there were no significant differences in these environmental parameters among the stations and seasons evaluated herein. The PCA reflected the same phenomenon: Granularity of the sediment was the most important factor on axis 1 and water temperature was the most important factor on axis 2.

15 Vertical distribution of meiobenthos in soft sediments can be affected by various factors, including mechanical properties of the sediment, oxygen regime, and seasonality (Jansson, 1967; Fenchel and Riedl, 1970; Pavlyuk, 1984; Galtsova, 1991; Kim et al., 2000; Huang et al., 2005). In this study, most of the meiofauna, especially the nematodes and copepods, were found in the $0-5 \mathrm{~cm}$ layer (i.e., the surface of sediment); similar results were reported by Armenteros et al. (2009) for Cienfuegos, Caribbean Sea and Zhang et al. for Huanghe River and Jiaozhou Bay (2001a, b). This vertical distribution was not obvious, however, for the polychaetes, which agrees with the results reported by Olga and Julia (2006). Oxygen deficiency can limit the penetration of animals into deeper sediments, and this may have affected the vertical polychaete distribution in Daya Bay.

The observed temporal variations may have been due to two main factors. First, trawling take place in autumn almost every year in Daya Bay, particularly in the vicinity of S4 and S8, and it occurred just before the samples were collected in the present study. The disturbance to the surface of the sediment and the benthic habitats caused
OSD

9, 1853-1885, 2012

\section{Temporal and spatial distribution of the meiobenthic community}

T. Ling et al.

\section{Title Page}


by trawling cannot be ignored, as it leads to release of suspended sediments (Churchill, 1989; Palanques et al., 2001), resuspension and burial of biologically recyclable organic materials (Mayer et al., 1991), and release of nutrients to the overlying water (Pilskaln et al., 1998; de Madron et al., 2005). Second, in Aotou Bay (near S4 and 5 S15), red tides usually appear in spring and summer every year (Song et al., 2004), and the affected area often is limited to the northern waters of the bay around the cage culture area. Many environmental factors can cause red tides; even in Daya Bay the cause of each red tide may not be exactly the same (Li et al., 1993; Xu et al., 2001a, b). The abrupt change in primary production that occurs during an algal bloom would 10 affect the quantity and structure of the meiobenthos (Armenteros et al., 2009).

Distribution of the biomass of the meiobenthos basically followed that of abundance, and the observed differences between the two to a large extent were due to the proportion of polychaetes. Polychaetes exhibited seasonal variation, as they were the second large taxonomic group in autumn and summer but not in winter and spring. This re15 sult differs from most other research. In this study, polychaetes were sensitive to water temperature and the granularity of sediment (i.e., positively correlated with temperature and significantly negatively correlated with the percentage of clay-silt and Md of the sediment), and they exhibited significant differences among stations and seasons and the interaction of station $\times$ season. The seasonal change in algae mentioned above would impact the quantity of copepods, which mainly feed on phytoplankton (Blanchard, 1991), and copepods are more affected than other meiofaunal by pollution in the environment (Raffaelli and Mason, 1981; Findlay, 1982). The dry weights of copepods (DW = 1.86) and polychaetes ( $D W=14$ ) differ greatly (Widbom, 1984), which lead to different distributions of biomass and abundance.

25 Diversity indices can be used as an indication of the diversity of a biological community, and the diversity of a community reflects its stability to some extent. The meiofaunal diversity indices of Daya Bay were low because of the large percentage of nematodes present $(95.60 \%)$. The Shannon-Wiener index, Simpson domination index, and Pielou's evenness index were significantly correlated with sediment granularity
OSD

$9,1853-1885,2012$

\section{Temporal and spatial distribution of the meiobenthic community}

T. Ling et al.

\section{Title Page}


and water content of the sediment, and they were different in different seasons. This result suggests that the diversity of the community likely is influenced by environmental variations.

\section{Conclusions}

5 This was the first study of the abundance, biomass, and temporal and spatial distribution of the meiobenthos in Daya Bay, South China Sea. The key results were as follows:

(1) Depth did not differ significantly among stations, and water temperature did differ significantly among seasons. Silt-clay and silt-sand were the main sediment types in Daya Bay. Water content of the sediment was influenced by granularity and was significantly negatively correlated with water depth. The content of Chl-a and OM did not differ significantly among stations and seasons;

(2) The absolute dominant taxonomic group was Nematoda, followed by Copepoda and Polychaeta. Community structure and abundance were significantly correlated with granularity of the sediment among stations, and had correlation with bottom water temperature among seasons;

(3) The biomass of the meiobenthos depended on the proportion of copepods/polychaetes, and it was significantly correlated with the percentage of claysilt and Md of the sediment;

(4) Most of the meiobenthos were found in the surface layer of the sediment, and as the largest group, nematodes had the main effect on quantity and proportion of the vertical distribution of the meiofauna;

(5) These results suggest that the meiobenthos was influenced by anthropogenic activities (e.g., trawling, red tides), which were apparent as seasonal changes in environmental parameters.

\section{OSD}

9, 1853-1885, 2012

\section{Temporal and spatial distribution of the meiobenthic community}

T. Ling et al.

\section{Title Page}

\section{Full Screen / Esc}

Printer-friendly Version

Interactive Discussion 
Acknowledgement. Financial support was provided by the CAS/SAFEA International Partnership Program for Creative Research Teams (No. KZCX2-YWT001). We thank the Granularity Laboratory of the South China Sea Institute of Oceanology, CAS for providing the sediment granularity data used in this study, and we thank Li Yong, He Shengyi, and Lin Chuanxu for 5 help with sampling.

\section{References}

Armenteros, M., Ruiz-Abierno, A., Fernández-Garcés, R., Pérez-García, J. A., Díaz-Asencio, L., Vincx, M., and Decraemer, W.: Biodiversity patterns of free-living marine nematodes in a tropical bay: Cienfuegos, Caribbean Sea, Estuar. Coast. Shelf. S., 85, 179-189, 2009.

10 Blanchard, G. F.: Measurement of meiofauna grazing rates on microphytobenthos: is primary production a limiting factor?, J. Exp. Mar. Biol. Ecol., 147, 37-46, 1991.

Boucher, G.: Structure and biodiversity of nematode assemblages in the SW lagoon of New Caledonia, Coral Reefs, 16, 177-186, 1997.

Branch, G. M. and Pringle, A.: The impact of the sand prawn Callianassa kraussi Stebbing on sediment turnover and on bacteria, meiofauna and benthic microflora, J. Exp. Mar. Biol. Ecol., 107, 219-235, 1987.

Christian, N., Renzo, P., and Gugielmo, T.: Seasonal dynamics of meiofauna in a South African temporarily open/closed estuary (Mdloti Estuary, Indian Ocean), Estuar. Coast. Shelf. S., 62, 325-338, 2005.

Churchill, J. H.: The effect of commercial trawling on sediment resuspension and transport over the Middle Atlantic Bight continental shelf, Cont. Shelf Res. 9, 841-864, 1989.

Clarke, K. R.: Non-parametric multivariate analyses of changes in community structure, Austral. J. Ecol., 18, 117-143, 1993.

Clarke, K. E. and Gorley, R. N.: PRIMER v6: User Manual/Tutorial, PRIMER-E, Plymouth, 2006.

Coull, B. C.: Role of meiofauna in estuarine soft-bottom habitats, Austral. J. Ecol., 24, 327-343, 1999.

Coull, B. C. and Chandler, G. T.: Meiobenthos, Encycl. Ocean Sci., 3, 1705-1711, 2001, http://www.ocean-sci.net/3/1705/2001/.
OSD

$9,1853-1885,2012$

\section{Temporal and spatial distribution of the meiobenthic community}

T. Ling et al.

\section{Title Page}

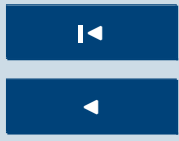

$\Delta$

Back

Close

\section{Full Screen / Esc}

Printer-friendly Version

Interactive Discussion 
Danovaro, R. and Gambi, C.: Biodiversity and trophic structure of nematode assemblages in seagrass systems: evidence for a coupling with changes in food availability, Mar. Biol., 141, 667-677, 2002.

Danovaro, R., Gambi, C., Manini, E., and Fabiano, M.: Meiofauna response to a dynamic river 5 plume front, Mar. Biol., 137, 359-370, 2000.

El-Wakeel, S. K. and Riley, J. P.: The determination of organic carbon in marine muds, J. Couns. Int. Explor., 22, 180-183, 1957.

Fenchel, T. M. and Riedl, R. J.: The sulfide system: a new biotic community underneath the oxidized layer of marine sand bottoms, Mar. Biol., 7, 255-268, 1970.

10 Findlay, S. E. G.: Influence of sampling scale on apparent distribution of meiofauna on a sandflat, Estuaries, 5(4), 322-324, 1982.

Galtsova, V. V.: Meiobenthos in marine ecosystems, in: Example of Free-Living Nematodes, Zoological Institute, USSR Academy of Sciences, Leningrad, 240 pp., 1991 (in Russian).

Gee, J. M.: Managing the health of seafloor, Front. Ecol. Environ., 1, 429-436, 1989.

15 Gerlach, S. A.: On the importance of marine meiofauna for benthos communities, Oecologia, 6, 176-190, 1971.

Giere, O.: Meiobenthology - The Microscopic Fauna in Aquatic Sediments. Springer Verlag, Berlin, Heidelberg, 1993.

Veit-Köhler, Gritta, Laudien, J., Knott, J., Velez, J., and Sahade, R.: Meiobenthic colonization of

20 soft sediments in arctic glacial Kongsfjorden (Svalbard), J. Exp. Mar. Biol. Ecol., 363, 58-65, 2008.

Heip, C., Vincx, M., and Vranken, G.: The ecology of marine nematodes, Oceanogr. Mar. Biol. Ann. Rev., 23, 399-489, 1985.

Higgins, R. and Thiel, H.: Introduction to the Study of Meiofauna, Smithsonian Inst. Press, Washington DC, London, 350, 1988.

Huang, Y., Zhang, Z., and Liu, X.: Studies on the community structures of meiofauna and marine nematode at six stations in the Southern Yellow Sea, China, J. Ocean Univ. China, 4(1), 3442, 2005.

Jansson, B.: The availability of oxygen for interstitial fauna of sandy beaches, J. Exp. Mar. Biol. Ecol., 1, 123-143, 1967.

Kim, D. S., Je, J. G., and Lee, J. H.: The community structure and spatial distribution of meiobenthos in the Kanghwa tidal flat, west coast of Korea, Ocean Res., 22(1), 15-23, 2000.
OSD

9, 1853-1885, 2012

\section{Temporal and spatial distribution of the meiobenthic community}

T. Ling et al.

\section{Title Page}

\section{Full Screen / Esc}

Printer-friendly Version

Interactive Discussion 
Li, J., Lu, S., and Liang, S.: Relationship between nutrients and red tide algae in Daya Bay and Dapeng Bay, Mar. Sci. Bull., 2(2), 23-29, 1993.

Liu, X. S.: Response of Meiofauna with Special Reference to Nematodes upon Recovery from Anthropogenic Activities in Subtropical Waters of Hong Kong, City University of Hong Kong, $5 \quad$ Hong Kong, 2009.

Liu, X. S., Xu, W. Z., Cheung, S. G., and Shin, P. K. S.: Response of meiofaunal community with special reference to nematodes upon deployment of artificial reefs and cessation of bottom trawling in subtropical waters, Hong Kong, Mar. Pollut. Bull., 2010.11.019, 2010.

de Madron, X. D., Ferre, B., Le Corre, G., Grenz, C., Conan, P., Pujo-Pay, M., Buscail, R., and Bodiot, O.: Trawling-induced resuspension and dispersal of muddy sediments and dissolved elements in the Gulf of Lion (NW Mediterranean), Cont. Shelf Res., 25, 2387-2409, 2005.

Mayer, L. M., Schick, D. F., Findlay, R. H., and Rice, D. L.: Effects of commercial dragging on sedimentary organic matter, Mar. Environ. Res., 31, 249-261, 1991.

Moens, T. and Vincx, M.: Temperature and salinity constraints on the life cycle of two brackish15 water nematode species, J. Exp. Mar. Biol. Ecol., 243, 115-135, 2000a.

Moens, T. and Vincx, M.: Temperature, salinity and food thresholds in two brackish-water bacterivorous nematode species: assessing niches from food absorption and respiration experiments, Mar. Ecol. Progress Ser., 53, 137-154, $2000 \mathrm{~b}$.

Nozais, C., Perissinotto, R., and Mundree, S.: Annual cycle of microalgal biomass in a South 20 African temporarily-open estuary: nutrient versus light limitation, Marine Ecol. Progress Ser., 223, 39-48, 2001.

Olafsson, E.: Elmgren. Seasonal dynamics of sublittoral meiobenthos in relation of phytoplankton sedimentation in the Baltic Sea, Estuar. Coast. Shelf S., 45, 149-164, 1997.

Olga, N. P.: Diurnal migrations of meiofauna in the sediments of sand bank of the Popov Island, the Sea of Japan, Russian J. Mar. Biol., 5, 64-65, 1984.

Olga, N. P. and Julia, A. T.: Meiobenthos in Nha Trang Bay of the South China Sea (Vietnam), Ocean Sci. J., 41(3), 139-148, 2006.

Olga, N. P., Yulia, T., Nguyen, V. T., and Nguyen, D. T.: Meiobenthos in Estuary Part of Ha Long Bay (Gulf of Tonkin, South China Sea, Vietnam), Ocean Sci. J., 43(3), 153-160, 2008.

30 Palanques, A., Guillen, J., and Puig, P.: Impact of bottom trawling on water turbidity and muddy sediment of an unfished continental shelf, Limnol. Oceanogr., 46, 1100-1110, 2001.

Pavlyuk, O. U.: Diurnal migrations of migrations of meiofauna in the sediments of sand bank of the popov Island, the Sea of Japan, Russian J. Mar. Biol., 5, 64-65, 1984.

OSD

9, 1853-1885, 2012

\section{Temporal and spatial distribution of the meiobenthic community}

T. Ling et al.

\section{Title Page}

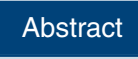

Introduction

Conclusions

Tables

References

Figures

14

4

Back

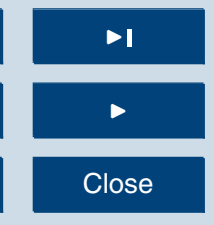

Full Screen / Esc

Printer-friendly Version

Interactive Discussion 
Pavlyuk, O. N., Preobrazhenskaya, T. V., and Tarasova, T. S.: Annual changes in meiobenthos community structure in Alekseev Bight, Sea of Japan, Russian J. Mar. Biol., 27(2), 105-110, 2001.

Pilskaln, C. H., Churchill, J. H., and Mayer, L. M.: Resuspension of sediment by bottom trawling 5 in the Gulf of Maine and potential geochemical consequences, Conserv. Biol., 12, 12231229, 1998.

Raffaelli, D. G. and Mason, C. F.: Pollution monitoring with meiofauna, using the ratio of nematode to copepod, Mar. Pollut. Bull., 12, 158-163, 1981.

Schratzberger, M., Whomersley, P., Warr, K., Bolam, S. G., and Rees, H. L.: Colonisation of various types of sediment by estuarine nematodes via lateral infaunal migration: a laboratory study, Mar. Biol., 145, 69-78, 2004.

Song, X. Y., Huang, L. M., Zhang, J. L., Huang, X. P., Zhang, J. B., Yin, J. Q., Tan, Y. H., and Liu, S.: Variation of phytoplankton biomass and primary production in Daya Bay during spring and summer, Marine Pollut. Bull., 49, 1036-1044, 2004.

Thiel, $\mathrm{H}$.: Benthos in upwelling regions, in: Upwelling Ecosystems, edited by: Boje, R. and Thomczak, M., Springer, Berlin, 124-138, 1978.

Veit-Kăhler, G., Laudien, J., Knott, J., Velez, J., and Sahade, R.: Meiobenthic colonization of soft sediments in arctic glacial Kongsfjorden (Svalbard), J. Exp. Mar. Biol. Ecol., 363, 58-65, 2008.

20 Wang, Y. S., Lou, Z. P., Sun, C. C., and Sun, S.: Ecological environment changes in Daya Bay, China, from 1982 to 2004, Marine Pollut. Bull., 56, 1871-1879, 2008.

Wang, Y. S., Lou, Z. P., Sun, C. C., Wu, M. L., and Han, S. H.: Multivariate statistical analysis of water quality and phytoplankton characteristics in Daya Bay, China, from 1999 to 2002, Oceanologia, 48, 193-211, 2006.

Welschmeyer, N. A.: Fluorometric analysis of chlorophyll-a in the presence of chlorophyll-a and pheopigments, Limnol. Oceanogr., 39, 1985-1992, 1994.

Widbom, B.: Determination of average individual dry weight and ash-free dry weight in different sieve fractions of marine meiofauna, Marine Biol., 84, 101-108, 1984.

Wiseman, J. D. H. and Bennette, H. E.: Distribution of organic matter and nitrogen in the sediments from the Arabian Sea, John Murray Exp., 3, 221, 1960.

Wu, M. L. and Wang, Y. S.: Using chemometrics to evaluate anthropogenic effects in Daya Bay, China, Estuar. Coast. Shelf S., 72, 732-742, 2007.
OSD

$9,1853-1885,2012$

\section{Temporal and spatial distribution of the meiobenthic community}

T. Ling et al.

Title Page

Abstract

Introduction

Conclusions

References

Tables

Figures

14

4

Back

Full Screen / Esc

Printer-friendly Version

Interactive Discussion 
Xu, G. Z.: Environments and Resources of Daya Bay, Anhui Science Publishing House, HeFei, China, 1989.

Xu, N., Chen, J., Wang, Z., Huang, W., Xie, L., and Qi, Y.: Dynamic analyses on algal bloom events in Daya Bay of Guangdong. A study of relationship between algal bloom and nutrients,

5 Acta Sci. Circum. (Huanjing Kexue Xue bao), 21, 400-404, 2001a (in Chinese with English Abstr.).

Xu, N., Chen, J. F., Wang, Z. H., Wang, Y., Huang, W., and Qi, Y. Z.: Dynamic analyses on several algal bloom events in Daya Bay of Guangdong I. Process of algal bloom and its relationship with environmental factors, Mar. Environ. Sci., 20(1), 1-12, 2001b.

10 Zhang, Z. N., Zhou, H., Guo, Y. O., and Mu, F. H.: Comparative study of the nematode community structure in the submarine delta of Huanghe River estuary and its adjacent waters, Oceanol. Limnol. Sinica, 32(4), 436-444, 2001a.

Zhang, Z. N., Zhou, H., Yu, Z. S., Han, J.: Abundance and biomass of the benthic meiofauna in the northern soft-bottom of the Jiaozhou Bay, Oceanol. Liminol. Sinica, 32, 139-147, 2001b

15 (in Chinese, with English Abstr.).

Zhang, Z. N., Mu, F. H., Yu, Z. S., and Zhou, H.: Abundance and biomass of the benthic meiofauna in the spawning group of anchovy (Engraulis japonicus) in the Southern Yellow Sea, China, J. Ocean Univ. Qingdao, 32(2), 251-258, 2002.

\section{OSD}

$9,1853-1885,2012$

\section{Temporal and spatial distribution of the meiobenthic community}

T. Ling et al.

\section{Title Page}

\section{Abstract}

Introduction

Conclusions

References

Tables

Figures

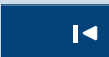

14

$\rightarrow 1$

4

Back

Close

Full Screen / Esc

Printer-friendly Version

Interactive Discussion 
OSD

$9,1853-1885,2012$

\section{Temporal and spatial distribution of the meiobenthic community}

Table 1. Correlations between environmental factors affecting the sediment in Daya Bay.

\begin{tabular}{lcccccccc}
\hline & Depth & Temperature & Salinity & $\begin{array}{c}\text { Clay-silt } \\
\text { content }\end{array}$ & $\mathrm{Md}_{\Phi}$ & $\begin{array}{c}\text { Water } \\
\text { content }\end{array}$ & $\begin{array}{c}\mathrm{OM} \\
\text { content }\end{array}$ & $\begin{array}{c}\text { Chl-a } \\
\text { content }\end{array}$ \\
\hline Depth & 1 & & & & & & & \\
Temperature & -0.183 & 1 & & & & & & \\
Salinity & $0.523^{* *}$ & -0.225 & 1 & & & & & \\
Clay-silt content & 0.142 & -0.043 & -0.195 & 1 & & & & \\
Md & 0.116 & -0.014 & -0.258 & $0.955^{* *}$ & 1 & & & \\
Water content & $-0.330^{*}$ & -0.035 & -0.239 & $0.355^{*}$ & $0.358^{*}$ & 1 & & \\
OM content & -0.212 & -0.036 & -0.121 & 0.165 & 0.168 & 0.311 & 1 & \\
Chl-a content & 0.044 & $-0.426^{* *}$ & 0.021 & 0.008 & 0.030 & -0.053 & -0.224 & 1 \\
\hline
\end{tabular}

${ }^{\star}$ Correlation is significant at the 0.05 level (2-tailed); ${ }^{*}$ Correlation is significant at the 0.01 level (2-tailed).
T. Ling et al.

Title Page

Abstract

Introduction

Conclusions

References

Tables

Figures

14

Back

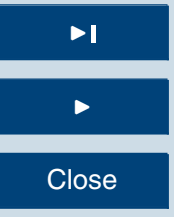

Full Screen / Esc

Printer-friendly Version

Interactive Discussion 
OSD

$9,1853-1885,2012$

\section{Temporal and spatial distribution of the meiobenthic community}

Table 2. Correlation between biotic variables and environmental parameters of Daya Bay.

\begin{tabular}{lcccccccc}
\hline & Depth & Temperature & Salinity & $\begin{array}{c}\text { Water } \\
\text { content }\end{array}$ & $\begin{array}{c}\text { OM } \\
\text { content }\end{array}$ & $\begin{array}{c}\text { Silt-clay } \\
\text { content }\end{array}$ & Md & Chl-a \\
\hline NO. of taxonomic group & 0.301 & $-0.747^{* *}$ & 0.137 & -0.120 & -0.031 & 0.039 & -0.006 & -0.294 \\
Abundance of meiofauna & $-0.361^{*}$ & 0.224 & -0.130 & -0.016 & -0.079 & $-0.516^{* *}$ & $-0.499^{* *}$ & -0.186 \\
Biomass of meiofauna & $-0.333^{*}$ & 0.243 & -0.095 & -0.256 & -0.047 & $-0.375^{*}$ & $-0.381^{*}$ & -0.091 \\
Abundance of nematodes & $-0.359^{*}$ & 0.210 & -0.129 & 0.001 & -0.078 & $-0.518^{* *}$ & $-0.500^{* *}$ & -0.194 \\
Abundance of copepods & -0.457 & -0.019 & 0.0 & -0.157 & -0.223 & -0.196 & -0.174 & -0.121 \\
Abundance of polychaetes & -0.239 & $0.456^{* *}$ & -0.135 & -0.137 & -0.002 & 0.035 & 0.022 & 0.184 \\
$\mathrm{H}^{\prime}$ & 0.210 & -0.003 & 0.114 & $-0.450^{* *}$ & 0.063 & 0.085 & 0.047 & 0.147 \\
$\mathrm{D}$ & 0.306 & $-0.775^{* *}$ & 0.126 & -0.074 & 0.024 & 0.157 & 0.116 & -0.222 \\
$\mathrm{~J}^{\prime}$ & 0.120 & 0.142 & 0.047 & $-0.430^{* *}$ & 0.085 & 0.129 & 0.094 & 0.239
\end{tabular}

T. Ling et al.

Title Page

\section{Abstract}

Introduction

Conclusions

References

Tables

Figures

14

- I

4

Back

Close

Full Screen / Esc

Printer-friendly Version

Interactive Discussion 
Table A1. Average abundance and biomass of major meiobenthic groups collected at four different seasons.

\begin{tabular}{|c|c|c|c|c|c|c|c|c|c|c|c|}
\hline \multirow[t]{2}{*}{ Group } & \multirow[t]{2}{*}{ Season } & \multicolumn{2}{|c|}{ Abundance } & \multicolumn{2}{|l|}{ Biomass } & \multirow[t]{2}{*}{ Group } & \multirow[t]{2}{*}{ Season } & \multicolumn{2}{|c|}{ Abundance } & \multicolumn{2}{|c|}{ Biomass } \\
\hline & & ind $/ 10 \mathrm{~cm}^{2}$ & $\%$ & $\mu \mathrm{g} / 10 \mathrm{~cm}^{2}$ & $\%$ & & & ind $/ 10 \mathrm{~cm}^{2}$ & $\%$ & $\mu \mathrm{g} / 10 \mathrm{~cm}^{2}$ & $\%$ \\
\hline \multirow[t]{4}{*}{ Nematoda } & Autumn & $546.7 \pm 212.0$ & 95.60 & $218.7 \pm 84.8$ & 55.02 & Copepoda & Autumn & $11.7 \pm 10.1$ & 1.55 & $21.8 \pm 18.7$ & 4.16 \\
\hline & Winter & $653.2 \pm 182.1$ & & $261.3 \pm 72.9$ & & & Winter & $15.6 \pm 10.7$ & & $28.9 \pm 19.9$ & \\
\hline & Spring & $1552.0 \pm 564.1$ & & $620.8 \pm 225.6$ & & & Spring & $14.4 \pm 9.0$ & & $26.8 \pm 16.8$ & \\
\hline & Summer & $1047.6 \pm 543.0$ & & $419.1 \pm 217.2$ & & & Summer & $20.0 \pm 9.5$ & & $37.3 \pm 17.6$ & \\
\hline \multirow[t]{4}{*}{ Polychaeta } & Autumn & $12.2 \pm 11.5$ & 1.39 & $170.3 \pm 161.1$ & 28.01 & Oligochaeta & Autumn & $5.61 \pm 6.45$ & 0.29 & $78.6 \pm 90.3$ & 5.92 \\
\hline & Winter & $6.2 \pm 4.2$ & & $86.1 \pm 59.3$ & & & Winter & $3.3 \pm 3.2$ & & $46.3 \pm 45.3$ & \\
\hline & Spring & $9.7 \pm 5.6$ & & $135.1 \pm 78.0$ & & & Spring & $2.1 \pm 1.9$ & & $29.1 \pm 26.1$ & \\
\hline & Summer & $27.3 \pm 34.1$ & & $382.1 \pm 477.7$ & & & Summer & $0.7 \pm 1.7$ & & $9.4 \pm 23.2$ & \\
\hline \multirow[t]{4}{*}{ Kinorhyncha } & Autumn & $2.1 \pm 3.2$ & 0.25 & $4.2 \pm 6.3$ & 0.70 & Gastrotricha & Autumn & $6.3 \pm 9.2$ & 0.20 & $21.6 \pm 32.5$ & 0.97 \\
\hline & Winter & $2.9 \pm 2.2$ & & $5.8 \pm 4.5$ & & & Winter & $0.3 \pm 0.5$ & & $1.1 \pm 1.7$ & \\
\hline & Spring & $2.92 \pm 1.61$ & & $5.8 \pm 3.2$ & & & Spring & $0.3 \pm 0.4$ & & $1.2 \pm 1.3$ & \\
\hline & Summer & $1.9 \pm 1.7$ & & $3.4 \pm 3.4$ & & & Summer & $0.8 \pm 1.7$ & & $3.0 \pm 3.6$ & \\
\hline \multirow[t]{4}{*}{ Ostracoda } & Autumn & $1.1 \pm 1.5$ & 0.18 & $28.9 \pm 39.4$ & 6.57 & Bivalvia & Autumn & $2.2 \pm 2.0$ & 0.17 & $9.4 \pm 8.4$ & 1.04 \\
\hline & Winter & $1.0 \pm 0.9$ & & $25.8 \pm 23.5$ & & & Winter & $0.8 \pm 1.0$ & & $3.5 \pm 4.4$ & \\
\hline & Spring & $4.2 \pm 5.4$ & & $109.4 \pm 140.3$ & & & Spring & $0.7 \pm 1.5$ & & $3.1 \pm 6.2$ & \\
\hline & Summer & $0.7 \pm 0.8$ & & $17.5 \pm 20.5$ & & & Summer & $3.1 \pm 2.0$ & & $12.8 \pm 8.6$ & \\
\hline \multirow[t]{4}{*}{ Turbellaria } & Autumn & $0.4 \pm 1.2$ & 0.10 & $1.6 \pm 4.1$ & 0.49 & Nemertinea & Autumn & $1.1 \pm 0.8$ & 0.09 & $3.9 \pm 2.7$ & 0.45 \\
\hline & Winter & $2.2 \pm 2.8$ & & $7.5 \pm 9.8$ & & & Winter & $0.7 \pm 0.8$ & & $2.3 \pm 2.7$ & \\
\hline & Spring & $1.2 \pm 1.2$ & & $4.3 \pm 4.3$ & & & Spring & $1.0 \pm 0.9$ & & $3.3 \pm 3.2$ & \\
\hline & Summer & & & & & & Summer & $0.8 \pm 1.5$ & & $2.9 \pm 5.2$ & \\
\hline \multirow[t]{4}{*}{ Sipuncula } & Autumn & $0.8 \pm 0.8$ & 0.06 & $2.3 \pm 2.6$ & 0.30 & Hydroida & Autumn & $0.7 \pm 1.9$ & 0.04 & $2.6 \pm 6.5$ & 0.19 \\
\hline & Winter & $0.4 \pm 0.3$ & & $1.2 \pm 1.2$ & & & Winter & $0.1 \pm 0.1$ & & $0.5 \pm 0.5$ & \\
\hline & Spring & $0.5 \pm 0.8$ & & $1.6 \pm 2.9$ & & & Spring & $0.3 \pm 0.4$ & & $1.0 \pm 1.3$ & \\
\hline & Summer & $0.8 \pm 1.8$ & & $2.8 \pm 6.1$ & & & Summer & $0.3 \pm 0.7$ & & $1.1 \pm 2.4$ & \\
\hline \multirow[t]{4}{*}{ Amphipoda } & Autumn & $0.3 \pm 1.0$ & 0.03 & $0.1 \pm 0.1$ & 0.11 & Cumacea & Autumn & $0.7 \pm 2.0$ & 0.02 & $2.4 \pm 6.7$ & 0.04 \\
\hline & Winter & $2.2 \pm 2.8$ & & $11.2 \pm 5.8$ & & & Winter & $0.0 \pm 0.1$ & & $0.6 \pm 1.0$ & \\
\hline & Spring & $0.1 \pm 0.2$ & & $0.8 \pm 2.5$ & & & Spring & & & & \\
\hline & Summer & $0.1 \pm 0.3$ & & $1.3 \pm 3.8$ & & & Summer & & & & \\
\hline \multirow[t]{4}{*}{ Halacaroidea } & Autumn & $0.3 \pm 0.7$ & 0.03 & $0.5 \pm 1.1$ & 0.03 & Others & Autumn & $0.1 \pm 0.2$ & 0.01 & $0.2 \pm 0.2$ & 0.04 \\
\hline & Winter & $0.0 \pm 0.1$ & & $0.0 \pm 0.1$ & & & Winter & $0.07 \pm 0.09$ & & $0.1 \pm 0.09$ & \\
\hline & Spring & $0.1 \pm 0.2$ & & $0.2 \pm 0.4$ & & & Spring & $0.1 \pm 0.2$ & & $0.2 \pm 0.2$ & \\
\hline & Summer & & & & & & Summer & $0.1 \pm 0.2$ & & $0.2 \pm 0.6$ & \\
\hline \multirow{2}{*}{ Total } & \multicolumn{6}{|c|}{ Abundance } & & & & & \\
\hline & \multicolumn{6}{|c|}{$993.57 \pm 455.36$ ind cm $^{-2}$} & \multicolumn{3}{|c|}{$690.51 \pm 205.0 \mu \mathrm{g} 10 \mathrm{~cm}^{-2}$} & & \\
\hline
\end{tabular}

(Others include Priapulida, Echinodermata, Tanaidacea, and Rotifera, which were rarely found.)
OSD

$9,1853-1885,2012$

\section{Temporal and spatial distribution of the meiobenthic community}

T. Ling et al.

\section{Title Page}

\section{Abstract}

Introduction

Conclusions

References

Tables

Figures
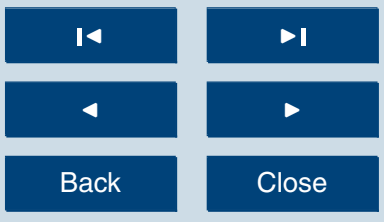

Full Screen / Esc

Printer-friendly Version

Interactive Discussion 


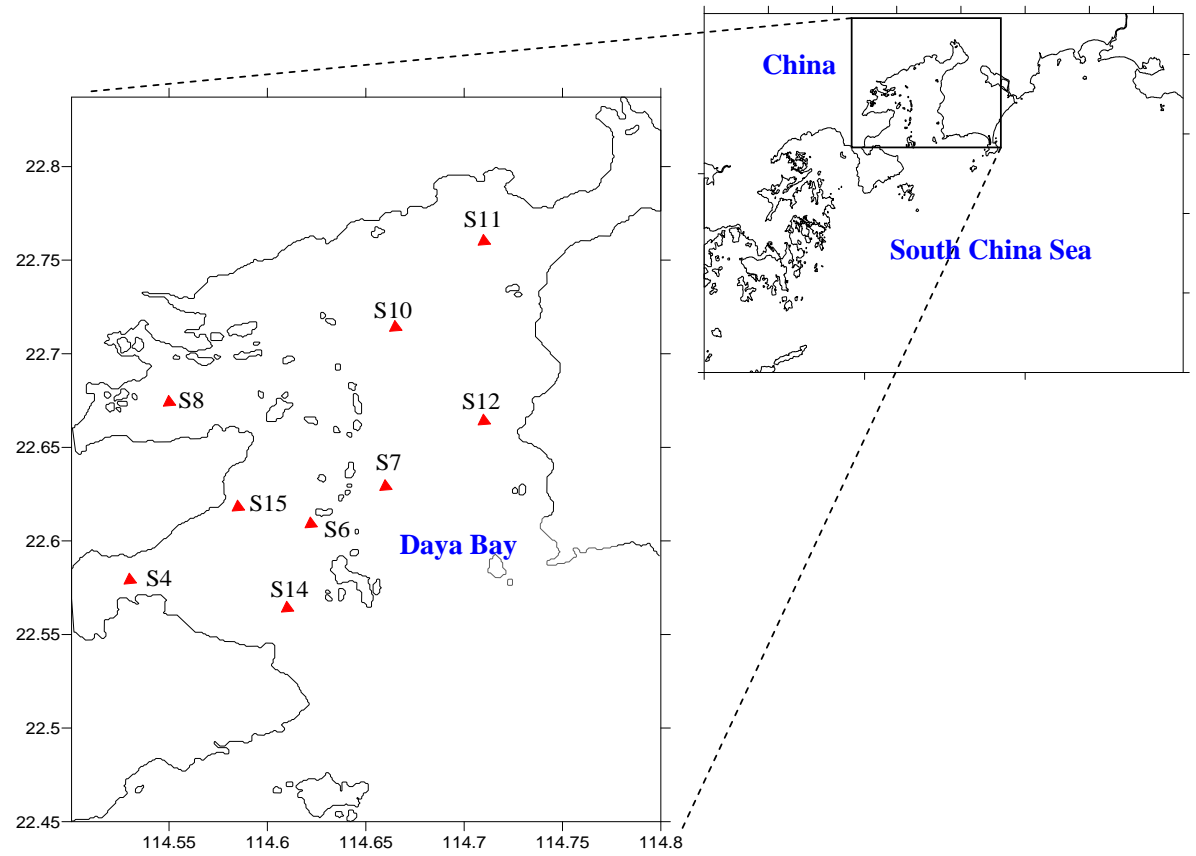

Fig. 1. Map of study area in Daya Bay with the locations of the nine sampling stations.

OSD

$9,1853-1885,2012$

\section{Temporal and spatial distribution of the meiobenthic community}

T. Ling et al.

Title Page

Abstract

Introduction

Conclusions

References

Tables

Figures

14

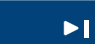

4

Back

Close

Full Screen / Esc

Printer-friendly Version

Interactive Discussion 


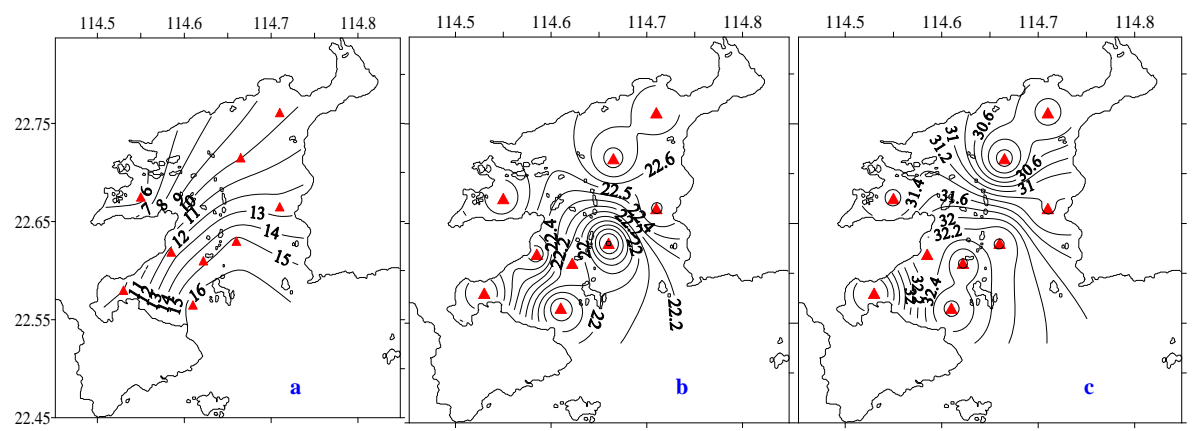

Fig. 2. The horizontal distribution of (a) depth $(\mathrm{m})$, (b) temperature $\left({ }^{\circ} \mathrm{C}\right)$, and $(\mathbf{c})$ salinity $(\% \circ)$ in Daya Bay.
OSD

9, 1853-1885, 2012

\section{Temporal and spatial distribution of the meiobenthic community}

T. Ling et al.

Title Page

Abstract

Introduction

Conclusions

References

Tables

Figures

14

4

Back

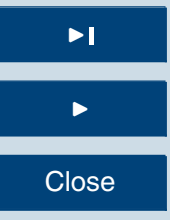

Full Screen / Esc

Printer-friendly Version

Interactive Discussion 

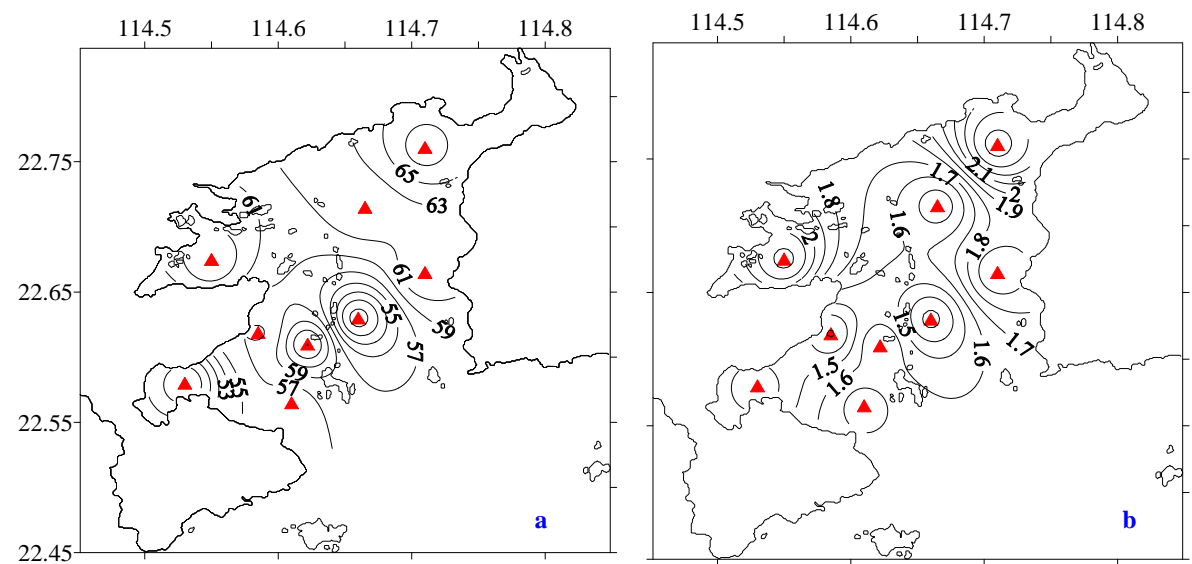

OSD

$9,1853-1885,2012$

\section{Temporal and spatial distribution of the meiobenthic community}

T. Ling et al.

Title Page

Abstract

Introduction

Conclusions

References

Tables

Figures

Fig. 3. The horizontal distribution of (a) water content (\%) and (b) OM (\%) in sediment samples collected in Daya Bay.

Full Screen / Esc

Printer-friendly Version

Interactive Discussion 

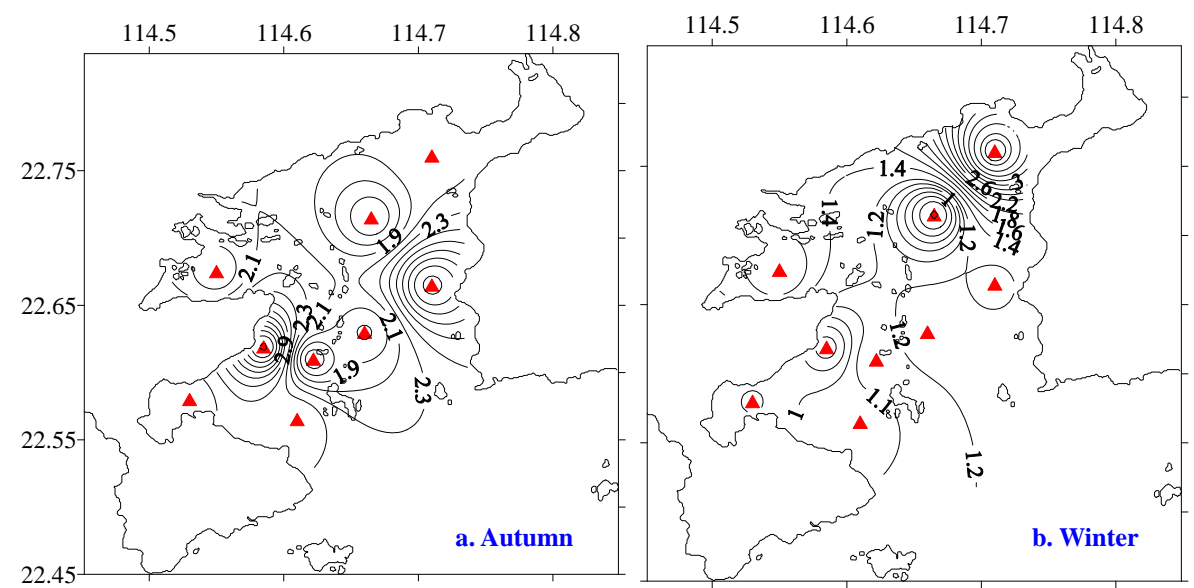

OSD

9, 1853-1885, 2012

\section{Temporal and spatial distribution of the meiobenthic community}

T. Ling et al.
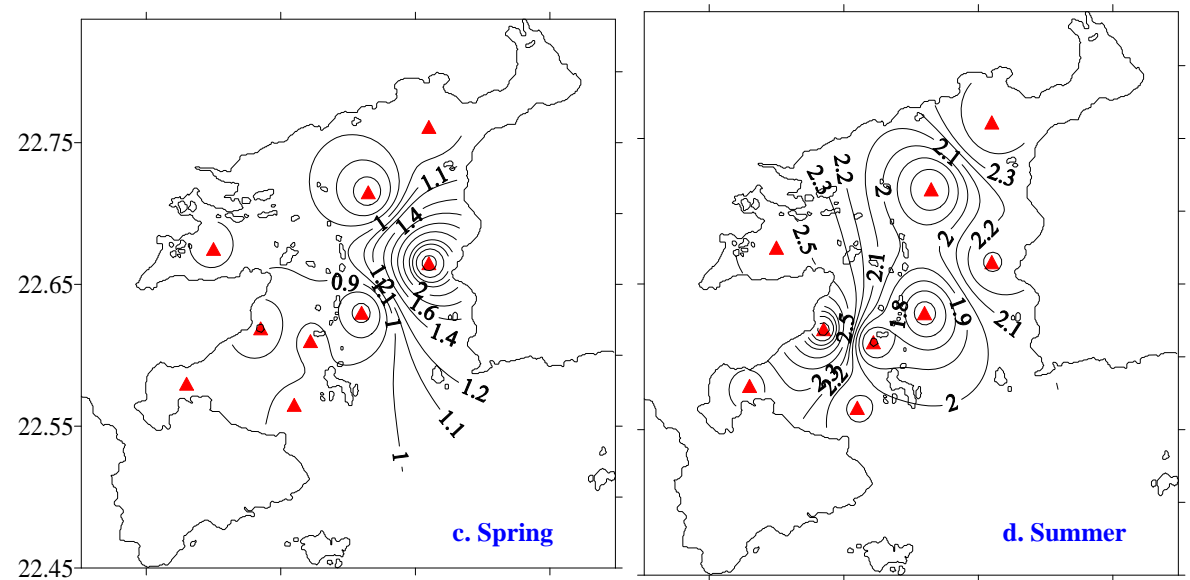

Title Page

Abstract

Introduction

Conclusions

References

Tables

Figures

14

4

Back

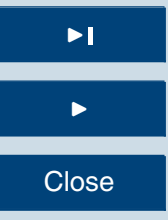

Full Screen / Esc

Fig. 4. The horizontal distribution of Chl-a in sediments collected in Daya Bay at four different time points.

Printer-friendly Version

Interactive Discussion 


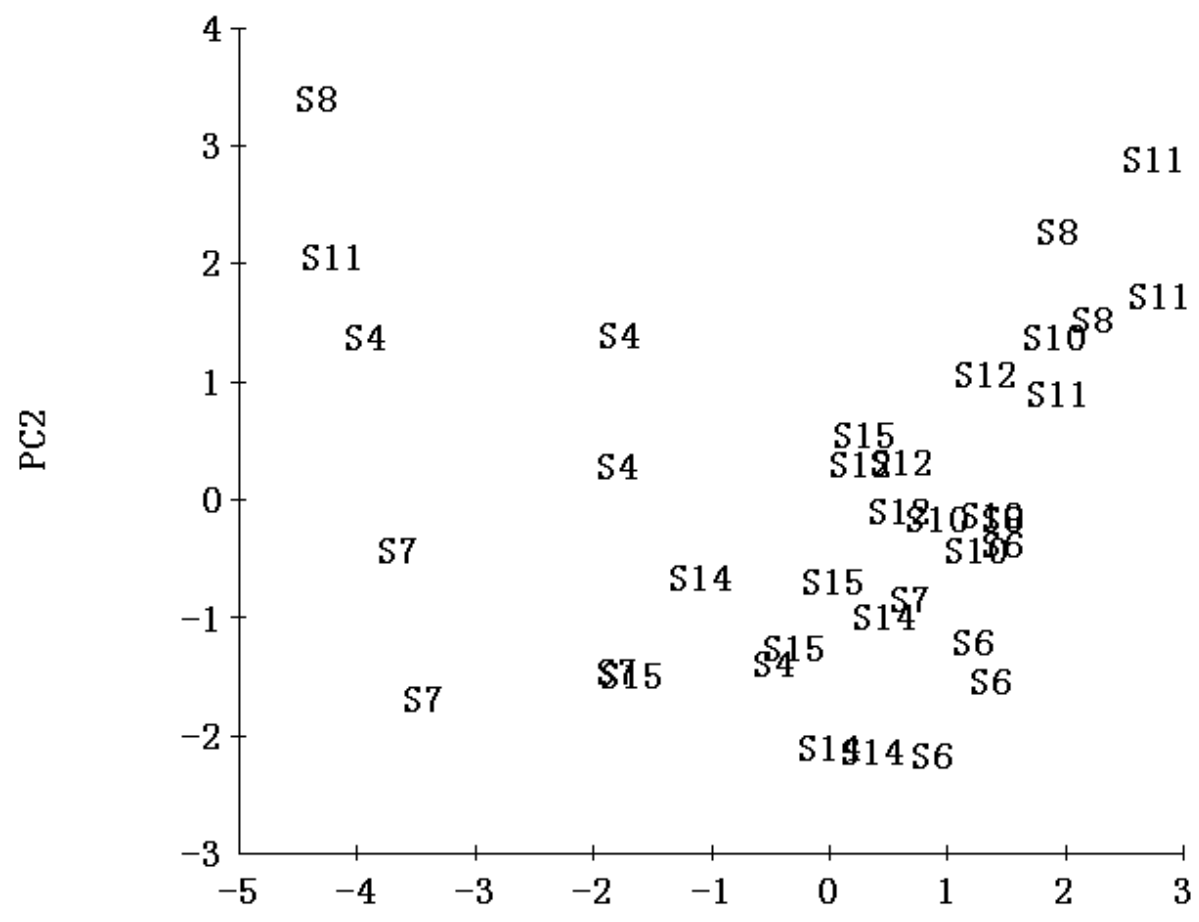

PC1

Fig. 5. Ordination of nine stations for four seasons based on principal component analysis.
OSD

9, 1853-1885, 2012

Temporal and spatial distribution of the meiobenthic community

T. Ling et al.

Title Page

Abstract

Introduction

Conclusions

References

Tables

Figures

14

4

Back

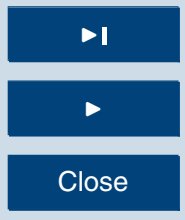

Full Screen / Esc

Printer-friendly Version

Interactive Discussion 
OSD

9, 1853-1885, 2012

\section{Temporal and spatial distribution of the meiobenthic community}

T. Ling et al.

\section{Title Page}

Abstract

Introduction

Conclusions

References

Tables

Figures

100

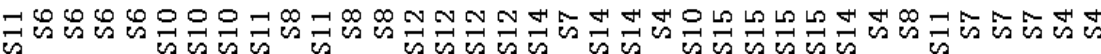

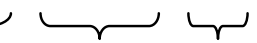

Group 1

Group 2

Group 3

Group 4 Group 5

Fig. 6. CLUSTER analysis of stations and seasons based on environmental parameters.

Interactive Discussion

\section{Full Screen / Esc}

Back

Close

Printer-friendly Version

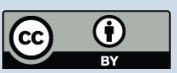




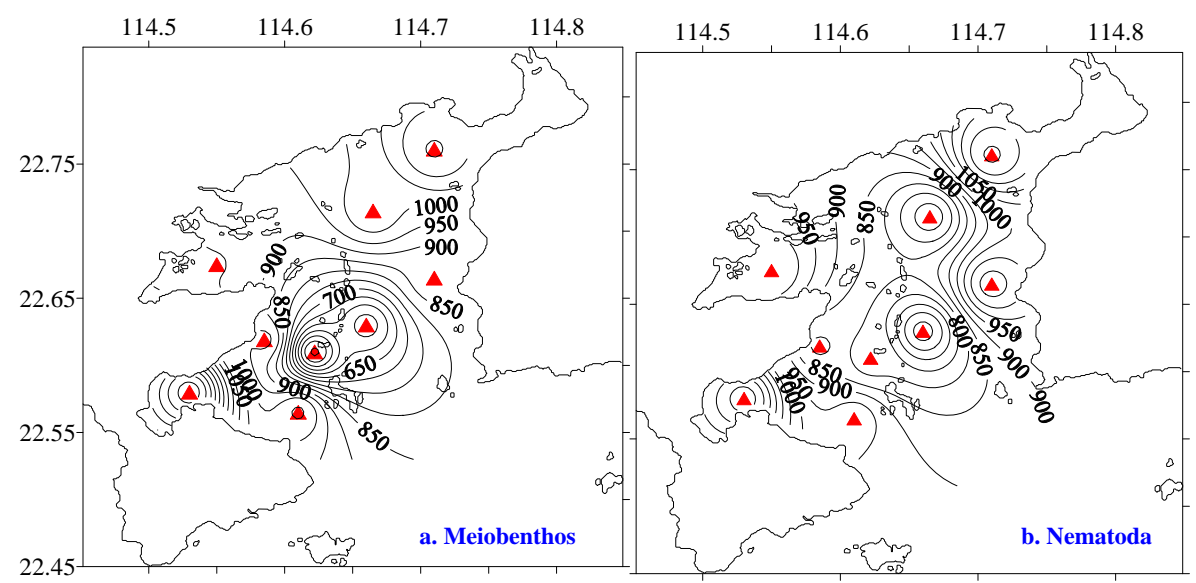

OSD

9, 1853-1885, 2012

\section{Temporal and spatial distribution of the meiobenthic community}

T. Ling et al.

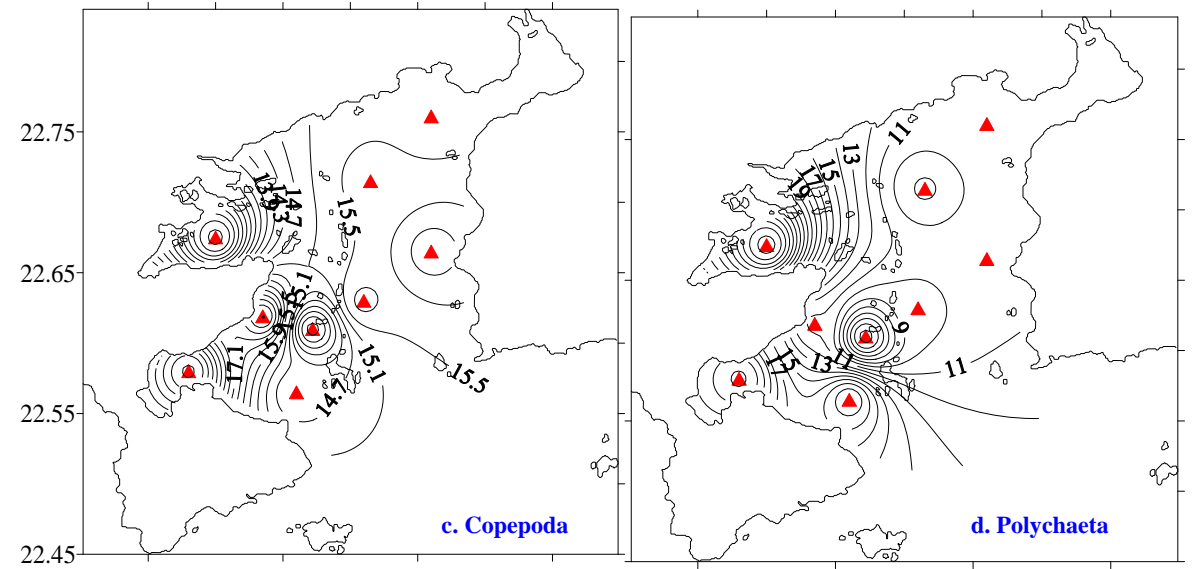

Title Page

Abstract

Introduction

Conclusions

References

Tables

Figures

14

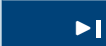

4

Back

Close

Full Screen / Esc

Printer-friendly Version

Fig. 7. The horizontal distribution of meiofauna and the main groups in Daya Bay.

Interactive Discussion 
a. Meiobenthos

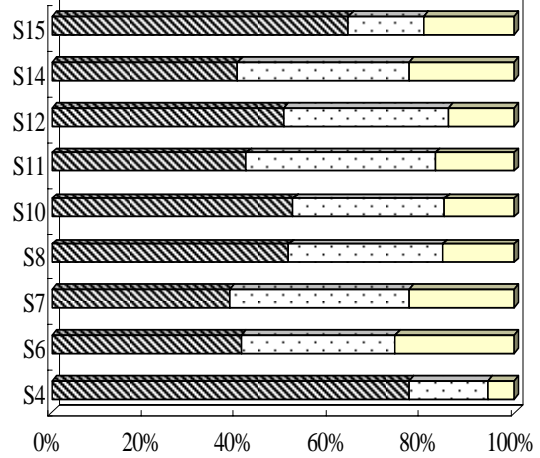

c. Copepods

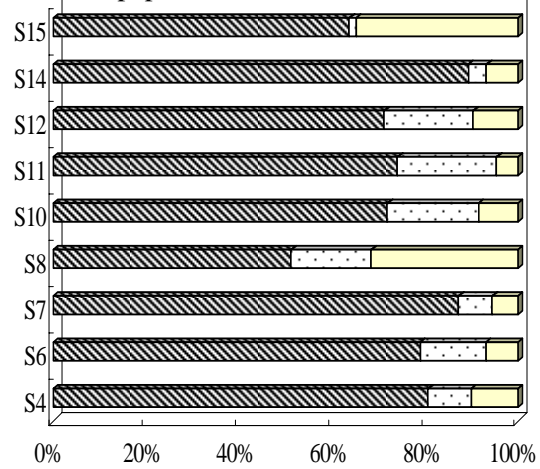

$\mathbb{N 0 - 2 \mathrm { cm }}$ $\square 2-5 \mathrm{~cm}$ b. Nematodes

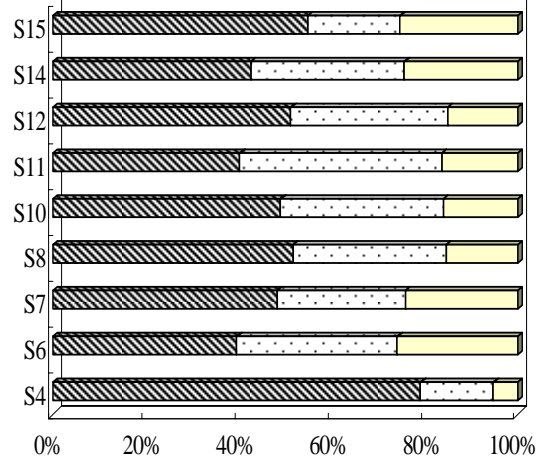

d. Polychaeta

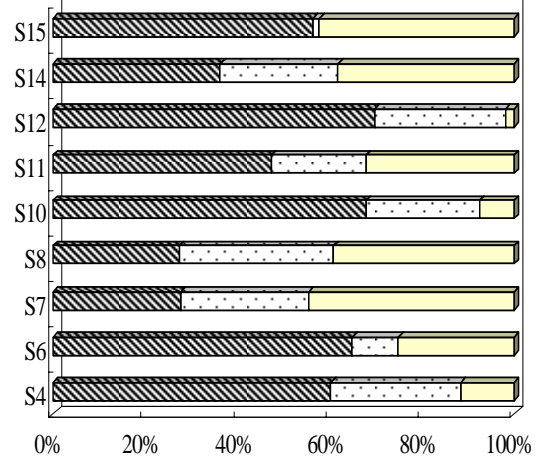

$\square 5-10 \mathrm{~cm}$
OSD

9, 1853-1885, 2012

\section{Temporal and spatial distribution of the \\ meiobenthic community}

T. Ling et al.

Title Page

Abstract

Introduction

Conclusions

References

Tables

Figures

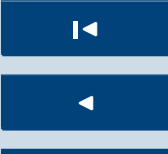

Back

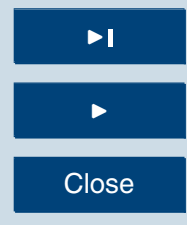

Full Screen / Esc

Printer-friendly Version

Interactive Discussion

Fig. 8. The vertical distribution of (a) total meiofauna and its major taxonomical groups: (b) nematodes, (c) copepods, and (d) polychaetes. 


\section{OSD}

$9,1853-1885,2012$

\section{Temporal and spatial distribution of the meiobenthic community}

T. Ling et al.

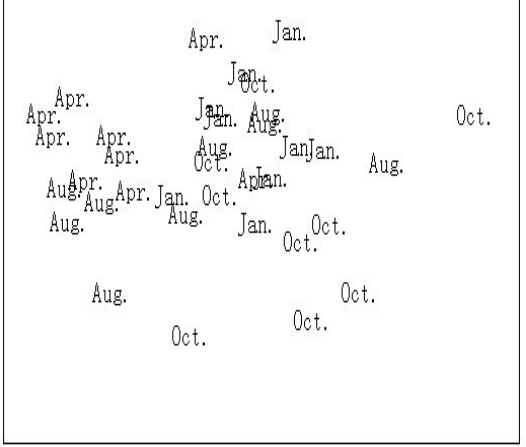

Fig. 9. Multidimensional scaling plots of meiobenthos assemblages based on fourth-root transformed abundance data from nine stations and four seasons. The plots are coded by stations and by seasons: Oct $=$ autumn, Jan $=$ winter, Apr $=$ spring, and Aug $=$ summer.
Title Page

Abstract

Introduction

Conclusions

References

Tables

Figures

14

- I

4

Back

Close

Full Screen / Esc

Printer-friendly Version

Interactive Discussion 